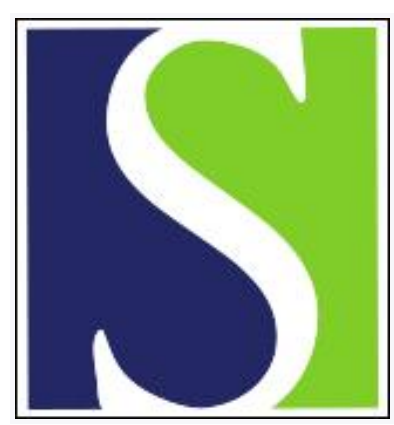

Scand J Work Environ Health 2011;37(4):341-348

https://doi.org/10.5271/sjweh.3157

Published online: 14 Mar 2011, Issue date: Jul 2011

Prenatal cell phone use and developmental milestone delays among infants

by Divan HA, Kheifets L, Olsen J

Affiliation: Division of Biostatistics, Department of Preventive Medicine, Keck School of Medicine, University of Southern California, 1540 Alcazar Street, CHP-222S, MC-9010, Los Angeles, CA 90089-9010, USA. divan@usc.edu

Key terms: cell phone; cellular phone; child development; developmental delay; infant; mobile phone; mother; offspring; pregnancy; prenatal

This article in PubMed: www.ncbi.nlm.nih.gov/pubmed/21403981

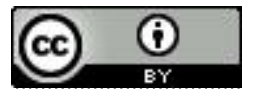




\title{
Prenatal cell phone use and developmental milestone delays among infants
}

\author{
By Hozefa A Divan, MSPH, PhD, ${ }^{1}$ Leeka Kheifets, MA, PhD, ${ }^{2}$ Jørn Olsen, MD, PhD ${ }^{2,3}$
}

\begin{abstract}
Divan HA, Kheifets L, Olsen J. Prenatal cell phone use and developmental milestone delays among infants. Scand J Work Environ Health. 2011;37(4):341-348. doi: 10.5271/sjweh.3157

Objective The aim of this study was to examine if prenatal use of cell phones by pregnant mothers is associated with developmental milestones delays among offspring up to 18 months of age.

Methods Our work is based upon the Danish National Birth Cohort (DNBC), which recruited pregnant mothers from 1996-2002, and was initiated to collect a variety of detailed information regarding in utero exposures and various health outcomes. At the end of 2008, over 41000 singleton, live births had been followed with the Age- 7 questionnaire, which collected cell-phone-use exposure for mothers during pregnancy. Outcomes for developmental milestones were obtained from telephone interviews completed by mothers at age 6- and 18-months postpartum.
\end{abstract}

Results A logistic regression model estimated the odds ratios (OR) for developmental milestone delays, adjusted for potential confounders. Less than $5 \%$ of children at age 6 and 18 months had cognitive/language or motor developmental delays. At 6 months, the adjusted OR was 0.8 [95\% confidence interval (95\% CI) $0.7-1.0]$ for cognitive/ language delay and $0.9(95 \% \mathrm{CI} 0.8-1.1)$ for motor development delay. At 18 months, the adjusted OR were 1.1 (95\% CI 0.9-1.3) and 0.9 (95\% CI 0.8-1.0) for cognitive/language and motor development delay, respectively.

Conclusions No evidence of an association between prenatal cell phone use and motor or cognitive/language developmental delays among infants at 6 and 18 months of age was observed. Even when considering doseresponse associations for cell phone use, associations were null.

Key terms cellular phone; child development; mobile phone; mother; offspring; pregnancy.

Only a decade ago, approximately $5 \%$ of the worldwide population used cell phones as a regular tool for communication. Nowadays both access and use of cell phones has become nearly universal with the developing world seeing the greatest increase in use per individual in this time period (1). By the end of 2010, there were an estimated 5 billion cell phone subscribers worldwide (2).

During this time of rapid technological growth, the potential adverse health effects from cell phones have become a contentious topic debated among the scientific community as well as the general public. Early studies have focused on the use of cell phones and the risks for brain or other cancers of the head (3-5). Recently, the International Agency for Research on Cancer categorized radiofrequency electromagnetic fields, such as those associated with cell phones, as a possible carcinogen to humans based upon epidemiological studies of gliomas, which are one form of brain cancer (6). Numerous other health outcomes besides cancers are yet to be comprehensively evaluated. Previously, we reported findings that exposure to cell phone use prenatally as well as postnatally was associated with emotional and hyperactivity-like behavior among children by the age of seven (7). A subsequent analysis reported the same findings and considered the influence of other important factors for behavioral problems (8). We concluded that while it is still premature to consider these associations as causal, the public health implications for pregnant mothers and children are large if these associations are real.

For many environmental health exposures (such as lead, ionizing radiation, or particulate matter), children are more susceptible and succumb to greater adverse

\footnotetext{
${ }^{1}$ Division of Biostatistics, Department of Preventive Medicine, Keck School of Medicine, University of Southern California, Los Angeles, CA, USA.

2 Department of Epidemiology, School of Public Health, University of California, Los Angeles, USA.

3 Institute of Public Health, University of Aarhus, Aarhus, Denmark.
}

Correspondence to: Hozefa A Divan, Division of Biostatistics, Department of Preventive Medicine, Keck School of Medicine, University of Southern California, 1540 Alcazar Street, CHP-222S, MC-9010, Los Angeles, CA 90089-9010, USA. [E-mail: divan@usc.edu] 
health outcomes compared to adults exposed to similar levels. The same may be true for radiofrequency fields (RF) (9). RF exposure at high levels may lead to heating resulting in thermal effects specifically on the neurological development of the fetus and continued neurological growth of the newborn child. Research modeling of specific absorption rates for RF from cell phones to the womb of pregnant mothers suggests that exposure is low and not high enough to elevate the body temperature (thermal effect) $(10,11)$. Recently, in a controlled experiment with healthy participants, researchers with the US National Institutes of Health reported observing increased brain glucose metabolism in the region closest to the cell phone antenna when the device was in operation. If confirmed by other studies, this would imply that there may be a biological, nonthermal effect from cell phones (12). Institutions such as the World Health Organization and the National Academy of Sciences have specifically advocated for increased research efforts into the possible health effects from cell phones and other new sources of exposure to radiofrequency fields especially for children and fetuses $(13,14)$.

In the first year of an infant's life, the brain doubles in physical size. While the number of neurons is thought to remain the same throughout our lives, changes occur to the synaptic connections over time. It is estimated that there are over 1 trillion new connections formed during infancy and childhood (15). These connections are mediated via various biological processes such as neurogenesis, axonal and dendritic growth, synaptogenesis, cell death, synaptic pruning, myelination, and gliogenesis (16). These connections are stimulated by the interaction with people and objects in the environment.

There is a variation in the age where children are able to perform certain tasks, and the frequencies of delays is determined by the cut-off point used for classification - often at the $5-10 \%$ level $(17,18)$. Among infants, physical development is reflected by control over motor skills. Constant repetition of these actions leads to increased physical strength and improved motor coordination (19). Within a few months, an infant is lifting or tracking an object by moving his head. By four or five months of age, a child can roll over; soon afterwards, he or she can sit upright in a high chair, and then gradually pull him- or herself into a sitting position. After learning to roll, the child may begin to crawl. Before learning to walk around the age of 12 months, an infant will learn to stand with help and pull him- or herself up (19). Cognitive development during infancy is typified by sensorimotor activity. Infants use their senses to process their environment. They also learn to communicate through crying, babbling, or making sounds.
In this analysis, we explored the association of maternal cell phone use during pregnancy with developmental milestone delays of motor, cognitive, and language milestones at age 6 and 18 months among offspring.

\section{Methods}

\section{Subjects}

The Danish National Birth Cohort (DNBC) began recruitment of pregnant women in March 1996 and concluded in November 2002 encompassing over 100000 pregnancies $(20,21)$. Mothers and their offspring comprise two fixed cohorts to be followed over their lifetime. Data collection had been conducted by means of four telephone interviews - two during pregnancy and two at age 6 and 18 months (22). In 2005, an internetbased questionnaire administered to mothers to assess the child's health status was initiated when their offspring reached 7 years. Data on social conditions, family lifestyles, and childhood diseases were collected. This article is based on the information about children in the cohort born between 1997-2002 who had turned 7 years of age by January 2009 and whose mothers had a completed Age-7 questionnaire, either web- or paper-based.

\section{Exposure}

Questions regarding cell phone use during pregnancy (prenatal use) were included in the Age-7 questionnaire. Mothers reported whether they used a cell phone during their pregnancy for the child for whom the questionnaire was directed. Mothers also answered detailed questions on: (i) historical use of cell phone by mother (years since first use, trimester of use during pregnancy); (ii) average times spoken daily on phone during pregnancy; (iii) location of the phone when not in use (handbag or clothing pocket) during pregnancy; (iv) proportion of time that phone was powered on during pregnancy; and (v) use of earpiece (hands-free equipment) during pregnancy.

\section{Covariates}

Covariates of interest included parental history of developmental delays, pre-pregnancy body mass index (BMI), time to pregnancy, combined socio-occupational status of parents, prenatal intake of fish and alcohol, smoking, pre-eclampsia, gestational age, parents' ages at birth of child, birth weight, parity, household density, postpartum depression, breast feeding, amount of time spent with child, and child's time in daycare. Except for birth-related information, these covariates were collected at various 
time points corresponding to a particular DNBC interview or questionnaire. Covariates related to birth were linked to participants' study information utilizing a unique central personal registration (CPR) number, which is issued to all persons who are born in or who immigrate to Denmark (23). The Danish national birth register provided data on gestational age, birth weight, and parity (24). Not all potential confounders (covariates) considered in the descriptive analysis were later used in the regression analyses. Only those covariates determined to be of interest were selected and are presented in the results section.

\section{Outcomes}

The DNBC's third and fourth interviews correspond to the age when the offspring turned age 6 and 18 months. They contained a series of questions developed by an experienced child neuropsychologist on the basis of existing validated instruments to assess motor, cognitive, and language milestone delays as reported by the mother. Given study conditions (large sample size and use of telephone interviews) this was seen as the best option. For the 6-month interview, mothers answered "yes or no" to 14 questions pertaining to their infant's development at interview time. Eight questions assessed cognitive and language development (ie, infant looks in the direction of sounds or voices, throws a toy to the floor, makes sounds while playing, mimics sounds, seeks attention from parent, expresses dislikes, puts objects in their mouth, and enjoys playing airplane). Motor development was assessed by a series of six questions (ie, the infant can hold up his/her head, sit with his/her back straight, roll from his/her back to front, sit upright on the floor, grab objects out of reach, and crawl on stomach). An overall delayed developmental score for motor ( $0-6$ points) and cognitive/language ( $0-8$ points) development was calculated by assigning 1 point for each "no" answered and summing over the group of questions. A higher score implied greater developmental delay.

In the 18-month interview, mothers answered 11 questions pertaining to delays in their infant. There were five questions pertaining to motor development delays, of which two questions assessed the age at which the infant could sit or walk without support. Those infants in the top $5 \%$ of the age distribution were categorized as "delayed" for these two milestones. This coincided with $>9$ months for sitting and $>16$ months for walking with no support. The other three "yes-or-no" questions assessed whether the infant could climb stairs, remove his/her socks and shoes, and drink from a cup or glass by his- or herself. Six cognitive and language development questions were also asked. These included fetching an object when requested, being able to make marks on paper or table, turning a picture upright in a book, using word-like sounds, putting two words together in a sentence, and being able to name or mention more than ten words. A developmental delay score for motor ( $0-5$ points) and cognitive/language (0-6 points) development at 18 months was calculated by assigning 1 point for each "no" answer and summing over the group of questions.

To summarize motor, cognitive and language milestones, we defined "delayed" as those infants whose scores for motor or cognitive/language development corresponded to the highest $5 \%$ of the all infants for each of the 4 summary measures (motor delay at 6 and 18 months, respectively, and cognitive/language delay at 6 and 18 months, respectively).

\section{Statistical analysis}

All singleton, live births followed until the administration of the Age-7 questionnaire by January 2009 were included in this analysis. Comparisons were made between covariates collected and reported prenatal cell phone use. A binary logistic regression was used for the four dichotomized outcomes. The regression analysis was also restricted to children between 5-7 months of age at the time of the 6-month interview and children between 18-20 months by the 18-month interview. The logistic regression model estimated the odds ratio (OR) and $95 \%$ confidence intervals $(95 \% \mathrm{CI})$ for developmental milestone delays, and adjustments included covariates controlling for potential confounders. Certain covariates (risk factors) were not associated with the outcome of interest in this analysis and were eliminated. In addition, certain covariates were not associated with exposure and were found not to be statistically significant $(\mathrm{P}>0.05)$ in a multivariate model that included the exposure and outcome. The log likelihood ratio test was utilized during the model building process to develop a parsimonious model by manually eliminating variables at $\mathrm{P}>0.05$.

Analysis was also conducted to consider potential dose-response patterns of prenatal cell phone exposure. Proxies of prenatal cell-phone-use intensity included the number of times per day speaking on the phone, location of phone when not in use, proportion of time phone was turned on, and the use of an earpiece with the cell phone. Reference categories were defined as the lowest category of exposure (ie, no use, used 0-1 times per day). When considering the location of phone when not in use, the reference group was "carried in bag" versus "carried in clothing pocket".

\section{Results}

These results are based on data collected from 41541 singleton, live births for whom the mother completed an Age-7 questionnaire (approximately $60 \%$ of those 
Table 1. Percent distribution of prenatal cell phone use by selected covariates $(\mathrm{N}=41541)$

\begin{tabular}{|c|c|c|c|}
\hline & $\begin{array}{c}\text { None } \\
(\mathrm{N}=24942)\end{array}$ & $\begin{array}{c}\text { Prenatal } \\
(\mathrm{N}=13938)\end{array}$ & $\begin{array}{c}\text { Do not know/ } \\
\text { missing } \\
(\mathrm{N}=2661)\end{array}$ \\
\hline \multicolumn{4}{|c|}{$\begin{array}{l}\text { Combined socio-occupational } \\
\text { status for mother and father }\end{array}$} \\
\hline High & 67.9 & 61.7 & 61.6 \\
\hline Medium & 25.5 & 28.8 & 30.7 \\
\hline Low & 2.5 & 4.6 & 3.6 \\
\hline Missing & 4.1 & 4.9 & 4.1 \\
\hline \multicolumn{4}{|c|}{ Birth weight of child (grams) } \\
\hline$<2500$ & 2.8 & 3.4 & 3.0 \\
\hline $2500-2999$ & 7.9 & 8.9 & 8.1 \\
\hline $3000-3499$ & 28.3 & 29.0 & 28.0 \\
\hline $3500-3999$ & 37.1 & 36.0 & 35.9 \\
\hline$>3999$ & 23.9 & 22.7 & 25.0 \\
\hline \multicolumn{4}{|l|}{ Year of birth } \\
\hline 1997-1999 & 50.2 & 32.0 & 28.4 \\
\hline 2000-2002 & 49.7 & 67.9 & 71.5 \\
\hline Missing & 0.1 & 0.0 & 0.1 \\
\hline \multicolumn{4}{|c|}{ Mother's age at child's birth (years) } \\
\hline $15-24$ & 5.8 & 12.8 & 8.5 \\
\hline $25-29$ & 37.8 & 39.0 & 37.7 \\
\hline $30-34$ & 40.3 & 34.7 & 38.5 \\
\hline $35-39$ & 14.4 & 12.0 & 13.3 \\
\hline$\geq 40$ & 1.7 & 1.5 & 2.0 \\
\hline \multicolumn{4}{|l|}{ Gender of child } \\
\hline Female & 48.7 & 49.3 & 45.9 \\
\hline Male & 51.2 & 50.7 & 54.0 \\
\hline Missing & 0.1 & 0.0 & 0.1 \\
\hline \multicolumn{4}{|c|}{ Gestational age at birth (weeks) } \\
\hline$<37$ & 4.5 & 5.2 & 4.3 \\
\hline $37-41$ & 86.2 & 85.4 & 86.3 \\
\hline$\geq 42$ & 9.0 & 9.2 & 9.1 \\
\hline Missing & 0.3 & 0.2 & 0.3 \\
\hline \multicolumn{4}{|l|}{ Parity } \\
\hline 0 & 40.6 & 48.8 & 39.4 \\
\hline 1 & 39.1 & 33.8 & 38.4 \\
\hline$\geq 2$ & 17.2 & 13.6 & 19.3 \\
\hline Missing & 3.1 & 3.8 & 3.0 \\
\hline \multicolumn{4}{|l|}{$\begin{array}{l}\text { Child breastfed for at least } \\
\text { the first six months }\end{array}$} \\
\hline Yes & 62.4 & 56.4 & 61.2 \\
\hline No & 16.0 & 22.4 & 19.4 \\
\hline Do not know/missing & 21.6 & 21.2 & 19.4 \\
\hline \multicolumn{4}{|c|}{$\begin{array}{l}\text { Child in regular daycare outside } \\
\text { the home at age 18-month interview }\end{array}$} \\
\hline Yes & 70.0 & 69.2 & 69.3 \\
\hline No & 9.5 & 7.5 & 10.4 \\
\hline Do not know/missing & 20.5 & 23.3 & 20.3 \\
\hline
\end{tabular}

eligible to participate by January 2009). Nearly 34\% of mothers used a cell phone during pregnancy between 1997-2002 (table 1). Prenatal cell phone use doubled between 1998-2001 (from 21\% to 46\%, data not shown). For almost all covariates, the percent not known or missing was small and similar across the exposure groups. Variables collected from the 6- and 18-month interviews, which had approximately $20 \%$ missing or not known, included (i) parental history of speech and literacy problems, (ii) breastfeeding, (iii) postpartum depression, (iv) childcare, and (v) hours spent together.
Prenatal exposure to cell phone use was associated with lower combined socio-occupational status, higher pre-pregnancy BMI, greater prenatal smoking, lower prenatal alcohol use, lower prenatal fish consumption, younger mothers and fathers at birth of child, and lower percentages of breastfeeding up to 6 months of age.

Table 2 presents the percents, OR and adjusted OR $\left(\mathrm{OR}_{\mathrm{adj}}\right)$ for specific developmental milestone delays by prenatal cell phone use. Overall these specific milestones showed no association with the exposure. Of note only were 2 specific cognitive/language development milestone delays at 6 months ["does not throw toys to floor" $\left(\mathrm{OR}_{\mathrm{adj}}=0.7\right)$ and "does not mimic sounds or voices" $\left.\left(\mathrm{OR}_{\mathrm{adj}}=0.9\right)\right]$ and another 2 at 18 months of age ["not putting two words together in a sentence" $\left(\mathrm{OR}_{\mathrm{adj}}=0.9\right)$ and "not able to name or mention more than 10 words" $\left.\left(\mathrm{OR}_{\mathrm{adj}}=0.9\right)\right]$. These results imply that infants of mothers who used a cell phone during pregnancy were less likely to have these types of delays.

Table 3 shows the distribution of overall developmental milestone delay scores for the four summary outcomes by prenatal cell phone use. Less than $2 \%$ of infants at 6 months of age had a cognitive/language developmental delay score of $\geq 3$, and around $2 \%$ of infants at 6 months of age had a motor developmental delay score of $\geq 4$. At age 18 months, around $2 \%$ of infants had a cognitive/ language developmental delay score of $\geq 4$, and between $3-4 \%$ of infants had a motor developmental delay score of $\geq 2$ (table 3 ). The percentage of missing/not known was similar across exposure groups, and comprised 20-23\% of all four measured outcomes.

OR were near the null value when comparing prenatal cell phone use to the four overall developmental delay outcomes among infants (table 4). At 6 months, the $\mathrm{OR}_{\text {adj }}$ were $0.8(95 \%$ CI $0.7-1.0)$ for cognitive/language delay and 0.9 (95\% CI 0.8-1.1) for motor development delay. At 18 months, associations were near the null for both overall developmental delays. These $\mathrm{OR}_{\mathrm{adj}}$ that also controlled for corresponding developmental delays at 6 months were 1.1 (95\% CI 0.9-1.3) and 0.9 (95\% CI 0.8-1.0) for cognitive/language and motor development delay, respectively.

Among those mothers who reported using cell phones $(\mathrm{N}=13$ 938), 15\% of mothers carried their cell phones in their clothing pockets, and 20\% reported using an earpiece during pregnancy (data not shown). Both characteristics are indications that a cell phone was more likely to be worn closer to the womb by these types of mothers, yet associations with overall developmental milestone delays among infants were not observed. Also, 52\% of mothers reported using a cell phone $0-1$ times per day during their pregnancy (tables 5 and 6). And another 11\% of mothers recalled speaking on the phone $\geq 4$ times a day. Nearly half of mothers reported having the cell phone turned on $100 \%$ of the time. Associations of prenatal cell 
Table 2. Percentages and odds ratios $(\mathrm{OR})$ of specific developmental milestone delays among infants by prenatal cell phone use ( $\mathrm{N}=41$ 541). $\left[\mathrm{OR}_{\mathrm{adj}}=\right.$ adjusted $\mathrm{OR} ; 95 \% \mathrm{Cl}=95 \%$ confidence interval. $]$

\begin{tabular}{|c|c|c|c|c|c|c|}
\hline & None & Prenatal & Do not know & $\mathrm{OR}$ & $\mathrm{OR}_{\mathrm{adj}}$ & $95 \% \mathrm{Cl}$ \\
\hline \multicolumn{7}{|l|}{ Age 6 months } \\
\hline \multicolumn{7}{|l|}{ Cognitive/language development delay } \\
\hline Does not seek attention from parent & 6.1 & 5.7 & 5.8 & 0.9 & 0.9 & $0.8-1.0$ a \\
\hline Does not expresses dislikes & 8.3 & 8.5 & 8.5 & 1.0 & 1.0 & $0.9-1.1^{\text {a }}$ \\
\hline Does not puts objects in mouth & 0.4 & 0.3 & 0.4 & 0.8 & 0.9 & $0.6-1.3^{a}$ \\
\hline Does not enjoy playing airplane & 2.3 & 2.4 & 2.3 & 1.0 & 1.1 & $0.9-1.3^{\text {a }}$ \\
\hline Does not look in the direction of sounds or voices & 0.3 & 0.2 & 0.2 & 0.7 & 0.7 & $0.4-1.1^{\mathrm{a}}$ \\
\hline Does not throw toys to floor & 5.6 & 4.0 & 5.7 & 0.7 & 0.7 & $0.7-0.8^{a}$ \\
\hline Does not make sounds while playing & 1.1 & 0.9 & 1.3 & 0.7 & 0.8 & $0.6-1.0^{a}$ \\
\hline Does not mimic sounds or voices & 19.2 & 17.5 & 19.1 & 0.8 & 0.9 & $0.8-0.9$ a \\
\hline \multicolumn{7}{|l|}{ Motor developmental delay } \\
\hline Cannot hold head up & 0.1 & 0.1 & 0.2 & 1.0 & 0.9 & $0.5-1.9 \mathrm{~b}$ \\
\hline Cannot sit with back straight & 8.0 & 7.5 & 7.3 & 0.9 & 0.9 & $0.8-1.0^{b}$ \\
\hline Cannot roll from back to front & 22.4 & 23.9 & 23.8 & 1.0 & 1.0 & $1.0-1.1^{b}$ \\
\hline Cannot sit upright alone & 56.3 & 55.9 & 58.8 & 0.9 & 0.9 & $0.9-1.0^{b}$ \\
\hline Cannot grab for objects out of reach & 1.2 & 1.0 & 1.2 & 0.8 & 0.8 & $0.7-1.1^{\mathrm{b}}$ \\
\hline Cannot crawl on stomach & 36.6 & 36.0 & 38.1 & 1.0 & 1.0 & $0.9-1.0^{b}$ \\
\hline \multicolumn{7}{|l|}{ Age 18 months } \\
\hline \multicolumn{7}{|l|}{ Cognitive/language development delay } \\
\hline Does not fetch an object when requested & 1.3 & 1.2 & 1.6 & 1.0 & 1.0 & $0.8^{-1.2^{c}}$ \\
\hline Cannot make marks on paper or table & 3.5 & 3.7 & 4.2 & 1.1 & 1.0 & $0.9-1.1^{c}$ \\
\hline Does not turn pictures upright in books & 25.9 & 35.3 & 37.5 & 1.0 & 1.0 & $0.9-1.0 \mathrm{c}$ \\
\hline Does not use word-like sounds & 1.9 & 1.8 & 2.7 & 1.0 & 1.0 & $0.8-1.1^{c}$ \\
\hline Does not put two words together in a sentence & 43.2 & 39.7 & 45.6 & 0.9 & 0.9 & $0.8-0.9 \mathrm{c}$ \\
\hline Cannot name or mention more than 10 words & 45.5 & 42.0 & 48.1 & 0.9 & 0.9 & $0.8-0.9^{c}$ \\
\hline \multicolumn{7}{|l|}{ Motor developmental delay } \\
\hline Cannot sit without support & 3.8 & 3.8 & 4.1 & 1.0 & 1.0 & $0.9-1.2^{d}$ \\
\hline Cannot walk without support & 5.4 & 4.8 & 5.0 & 0.9 & 0.9 & $0.8^{-1.0^{d}}$ \\
\hline Cannot climb stairs & 2.2 & 2.1 & 2.5 & 0.9 & 0.9 & $0.8^{-1.1^{d}}$ \\
\hline Cannot remove socks and shoes & 13.8 & 12.8 & 15.3 & 0.9 & 0.9 & $0.9-1.0^{d}$ \\
\hline Cannot drink from cup by themselves & 0.8 & 0.8 & 1.1 & 1.1 & 1.1 & $0.9-1.5^{d}$ \\
\hline
\end{tabular}

${ }^{a}$ Adjusted for gender of child, combined socio-occupational status, gestational age, parity, and child's year of birth.

${ }^{\mathrm{b}}$ Adjusted for gender of child, combined socio-occupational status, mother's age at birth, gestational age, and child's birth weight.

${ }^{c}$ Adjusted for gender of child, combined socio-occupational status, gestational age, and breast feeding up to six months of age.

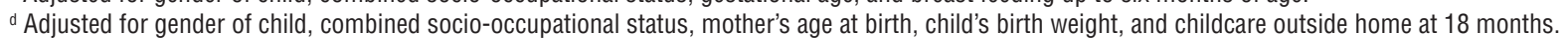

Table 3. Percent distribution of overall developmental milestone delays among infants by prenatal cell phone use $(\mathrm{N}=41541)$.

\begin{tabular}{|c|c|c|c|}
\hline & $\begin{array}{c}\text { None } \\
(\mathrm{N}=24942)\end{array}$ & $\begin{array}{c}\begin{array}{c}\text { Prenatal } \\
(\mathrm{N}=13 \text { 938) }\end{array} \\
\end{array}$ & $\begin{array}{c}\text { Do not know } \\
\text { Missing } \\
(\mathrm{N}=2661)\end{array}$ \\
\hline \multicolumn{4}{|c|}{ Age 6 months milestones scores } \\
\hline \multicolumn{4}{|c|}{ Cognitive/language developmental delay } \\
\hline Low $(0-2)$ & 76.5 & 77.7 & 79.3 \\
\hline High (3-8) & 1.8 & 1.4 & 1.7 \\
\hline Do not know/missing & 21.7 & 20.9 & 19.0 \\
\hline \multicolumn{4}{|c|}{ Motor developmental delay } \\
\hline $\operatorname{Low}(0-3)$ & 76.2 & 77.2 & 78.7 \\
\hline $\operatorname{High}(4-6)$ & 2.1 & 2.0 & 2.3 \\
\hline Do not know/missing & 21.7 & 20.8 & 19.0 \\
\hline \multicolumn{4}{|c|}{ Age 18 months milestones scores } \\
\hline \multicolumn{4}{|c|}{ Cognitive/language developmental delay } \\
\hline Low $(0-3)$ & 77.6 & 74.7 & 77.3 \\
\hline High (4-6) & 1.9 & 2.0 & 2.4 \\
\hline Do not know/missing & 20.5 & 23.3 & 20.3 \\
\hline \multicolumn{4}{|c|}{ Motor developmental delay } \\
\hline $\operatorname{Low}(0-1)$ & 75.4 & 73.2 & 74.9 \\
\hline High (2-5) & 3.6 & 3.1 & 4.2 \\
\hline Do not know/missing & 21.0 & 23.7 & 20.9 \\
\hline
\end{tabular}

Table 4. Odds ratio (OR) for overall developmental milestone delays among infants according to prenatal cell phone use ( $\mathrm{N}=41541)$. [95\% Cl=95\% confidence interval; $\mathrm{OR}_{\mathrm{adj}}=$ adjusted $\mathrm{OR}$.]

\begin{tabular}{|c|c|c|c|}
\hline & OR & $O \mathrm{R}_{\mathrm{adj}}$ & $95 \% \mathrm{Cl}$ \\
\hline \multicolumn{4}{|l|}{ Age 6 months outcomes } \\
\hline Cognitive/language developr & 0.8 & 0.9 & $7-1.0^{\mathrm{a}}$ \\
\hline Motor d & & & \\
\hline \multicolumn{4}{|l|}{ Age 18 months outcomes } \\
\hline & & & \\
\hline & & & \\
\hline & & & \\
\hline & & & \\
\hline \multicolumn{4}{|c|}{$\begin{array}{l}\text { a Adjusted for child's gender, combined social-occupational status, } \\
\text { gestational age, parity, and child's year of birth. }\end{array}$} \\
\hline \multicolumn{4}{|c|}{$\begin{array}{l}\text { 'Adjusted for child's gender, combined social-occupational status, } \\
\text { mother's age at birth, gestational age, and child's birth weight. }\end{array}$} \\
\hline \multicolumn{4}{|c|}{$\begin{array}{l}\text { 'Adjusted for child's gender, combined social-occupational status, } \\
\text { gestational age, and breast feeding up to six months of age. }\end{array}$} \\
\hline \multicolumn{4}{|c|}{$\begin{array}{l}\text { ¿Adjusted for child's gender, combined social-occupational status, moth- } \\
\text { er's age at birth, gestational age, and cognitive/language developmental } \\
\text { delay at six months of age. }\end{array}$} \\
\hline \multicolumn{4}{|c|}{$\begin{array}{l}\text { e Adjusted for child's gender, combined social-occupational status, mother's } \\
\text { age at birth, child's birth weight, and childcare outside home at } 18 \text { months. }\end{array}$} \\
\hline \multicolumn{4}{|c|}{$\begin{array}{l}\text { Adjusted for child's gender, combined social-occupational status, moth- } \\
\text { er's age at birth, child care outside the home at } 18 \text { months and motor } \\
\text { developmental delay at six months of age. }\end{array}$} \\
\hline
\end{tabular}


Table 5. Odds ratio (OR) for overall developmental milestone delays at age 6 months among infants according to mother's characteristics for prenatal cell phone use ( $\mathrm{N}=13$ 938). [95\% $\mathrm{Cl}=95 \%$ confidence interval; $O R_{\mathrm{adj}}=$ adjusted $\mathrm{OR}$.]

\begin{tabular}{|c|c|c|c|c|c|c|c|}
\hline & N & $\%$ & $\mathrm{OR}$ & $\begin{array}{c}\mathrm{P}- \\
\text { value }\end{array}$ & $\mathrm{OR}_{\mathrm{adj}}$ & $\begin{array}{c}\text { P- } \\
\text { value }\end{array}$ & $95 \% \mathrm{Cl}$ \\
\hline \multicolumn{8}{|c|}{$\begin{array}{l}\text { Cognitive/language } \\
\text { development delay }\end{array}$} \\
\hline $\begin{array}{l}\text { Times spoken } \\
\text { per day }\end{array}$ & & & & 0.3 & & 0.3 & \\
\hline $0-1$ & 7444 & 52.2 & 1.0 & & 1.0 & & \\
\hline $2-3$ & 3778 & 26.5 & 1.0 & & 1.0 & & $0.7-1.4$ a \\
\hline$\geq 4$ & 1529 & 10.7 & 0.8 & & 0.8 & & $0.4-1.3^{a}$ \\
\hline Missing & 1489 & 10.6 & - & & - & & \\
\hline $\begin{array}{l}\text { Percentage of } \\
\text { time turned on }\end{array}$ & & & & 0.3 & & 0.4 & \\
\hline 0 & 1129 & 7.9 & 1.0 & & 1.0 & & \\
\hline$<50$ & 1825 & 12.8 & 1.1 & & 1.1 & & $0.6-1.9^{\mathrm{a}}$ \\
\hline 50-99 & 4305 & 30.2 & 0.8 & & 0.9 & & $0.5-1.6^{\text {a }}$ \\
\hline 100 & 6877 & 48.3 & 1.1 & & 1.0 & & $0.5-2.0^{\mathrm{a}}$ \\
\hline Missing & 104 & 0.8 & - & & - & & \\
\hline \multicolumn{8}{|c|}{$\begin{array}{l}\text { Motor development } \\
\text { delay }\end{array}$} \\
\hline $\begin{array}{l}\text { Times spoken } \\
\text { per day }\end{array}$ & & & & 0.2 & & 0.1 & \\
\hline $0-1$ & 7444 & 52.2 & 1.0 & & 1.0 & & \\
\hline $2-3$ & 3778 & 26.5 & 0.8 & & 0.8 & & $0.5-1.0^{b}$ \\
\hline$\geq 4$ & 1529 & 10.7 & 0.6 & & 0.6 & & $0.3-1.0^{b}$ \\
\hline Missing & 1489 & 10.6 & - & & - & & \\
\hline $\begin{array}{l}\text { Percentage of } \\
\text { time turned on }\end{array}$ & & & & 0.2 & & 0.2 & \\
\hline 0 & 1129 & 7.9 & 1.0 & & 1.0 & & \\
\hline$<50$ & 1825 & 12.8 & 1.3 & & 1.3 & & $0.8-2.7^{b}$ \\
\hline 50-99 & 4305 & 30.2 & 1.0 & & 1.1 & & $0.6-1.8^{b}$ \\
\hline 100 & 6877 & 48.3 & 1.1 & & 1.1 & & $0.6-2.0^{b}$ \\
\hline Missing & 104 & 0.8 & - & & - & & \\
\hline
\end{tabular}

${ }^{a}$ Adjusted for gender of child, combined social-occupational status, gestational age, parity, and child's year of birth.

b Adjusted for gender of child, combined social-occupational status, mother's age at birth, gestational age, and child's birth weight.
Table 6. Odds ratio (OR) for overall developmental milestone delays at age 18 months among infants according to mother's characteristics for prenatal cell phone use $(\mathrm{N}=13$ 938). [95\% $\mathrm{Cl}=95 \%$ confidence interval; $O \mathrm{R}_{\mathrm{adj}}=$ adjusted $\mathrm{OR} ; \mathrm{NA}=$ not available.]

\begin{tabular}{|c|c|c|c|c|c|c|c|c|c|}
\hline & N & $\%$ & $\mathrm{OR}_{\mathrm{V}}$ & $\begin{array}{c}P- \\
\text { value }\end{array}$ & $\mathrm{OR}_{\mathrm{adj}}$ & $\begin{array}{l}P- \\
\text { value }\end{array}$ & $95 \% \mathrm{Cl} \mathrm{C}$ & $\begin{array}{r}\mathrm{OR}_{\text {adj }} \begin{array}{l}\mathrm{P}- \\
\text { value }\end{array} \\
\end{array}$ & $95 \% \mathrm{Cl}$ \\
\hline \multicolumn{10}{|c|}{$\begin{array}{l}\text { Cognitive/language } \\
\text { development delay }\end{array}$} \\
\hline \multicolumn{2}{|c|}{$\begin{array}{l}\text { Times spoken } \\
\text { per day }\end{array}$} & & & 0.3 & & 0.3 & & 0.6 & \\
\hline $0-1$ & 7444 & 52.2 & 1.0 & & 1.0 & & & 1.0 & \\
\hline $2-3$ & 3778 & 26.5 & 0.9 & & 0.9 & & $0.6-1.2^{\mathrm{a}}$ & 0.9 & $0.6-1.3 \mathrm{~b}$ \\
\hline$\geq 4$ & 1529 & 10.7 & 0.7 & & 0.7 & & $0.4-1.2^{\text {a }}$ & 0.9 & $0.5-1.6^{b}$ \\
\hline Missing & 1489 & 10.6 & & & & & & & \\
\hline \multicolumn{2}{|c|}{$\begin{array}{l}\text { Percentage of } \\
\text { time turned on }\end{array}$} & & & 0.7 & & 0.7 & & 0.6 & \\
\hline 0 & 1129 & 7.9 & 1.0 & & 1.0 & & & 1.0 & \\
\hline$<50$ & 1825 & 12.8 & 1.1 & & 0.9 & & $0.6-1.6^{a}$ & 1.2 & $0.7-2.3^{b}$ \\
\hline 50-99 & 4305 & 30.2 & 1.0 & & 0.9 & & $0.5-1.5^{a}$ & 1.2 & $0.5-2.2^{b}$ \\
\hline 100 & 6877 & 48.3 & 1.1 & & 1.1 & & $0.6-2.0^{\text {a }}$ & 1.5 & $0.7-3.0^{b}$ \\
\hline Missing & 104 & 0.8 & & & . & & & & \\
\hline \multicolumn{10}{|c|}{$\begin{array}{l}\text { Motor development } \\
\text { delay }\end{array}$} \\
\hline \multicolumn{2}{|c|}{$\begin{array}{l}\text { Times spoken } \\
\text { per day }\end{array}$} & & & NA & & NA & & NA & \\
\hline $0-1$ & 7444 & 52.2 & 1.0 & & 1.0 & & & 1.0 & \\
\hline $2-3$ & 3778 & 26.5 & 0.7 & & 0.7 & & $0.6-1.0^{c}$ & 0.7 & $0.5-1.0$ \\
\hline$\geq 4$ & 1529 & 10.7 & 1.1 & & 1.1 & & $0.8-1.5^{c}$ & 1.2 & $0.8-1.8$ \\
\hline Missing & 1489 & 10.6 & & & & & & & \\
\hline \multicolumn{2}{|c|}{$\begin{array}{l}\text { Percentage of } \\
\text { time turned on }\end{array}$} & & & 0.5 & & 0.5 & & 0.4 & \\
\hline 0 & 1129 & 7.9 & 1.0 & & 1.0 & & & 1.0 & \\
\hline$<50$ & 1825 & 12.8 & 1.0 & & 1.0 & & $0.7-1.5^{c}$ & 1.1 & $0.7-1.8$ \\
\hline $50-99$ & 4305 & 30.2 & 1.0 & & 1.0 & & $0.7-1.6^{c}$ & 1.2 & $0.8-2.0$ \\
\hline 100 & 6877 & 48.3 & 1.2 & & 1.2 & & $0.8^{-2.0^{c}}$ & 1.3 & $0.8^{-2.3^{d}}$ \\
\hline Missing & 104 & 0.8 & & & & & & & \\
\hline
\end{tabular}

a Adjusted for gender of child, combined social-occupational status, gestational age, and breastfeeding up to six months of age.

${ }^{b}$ Adjusted for gender of child, combined social-occupational status, mother's age at birth, gestational age, and cognitive/language developmental delay at six months of age.

${ }^{c}$ Adjusted for gender of child, combined social-occupational status, mother's age at birth, child's birth weight, and child care outside home at 18 months.

d Adjusted for gender of child, combined social-occupational status, mother's age at birth, child care outside the home at 18 months and motor developmental delay at six months of age.

Vrijheid at el (25) published similar results reporting no association between prenatal exposure to cell phone use and neurodevelopment at 14 months of age among offspring. As in our results, both mental and psychomotor scores were not associated with exposure even when considering the reported number of calls spoken per day (dose-response).

When modeling specific absorption rates of RF to the womb of pregnant mothers, research suggests that exposures are likely low and not high enough to elevate the body temperature (26-28). But this modeling is based on numerous assumptions and extrapolations. And possible non-thermal effects of RF still remain of interest.

Throughout the study, mothers were not aware of our research hypothesis. The timing of data collection between interviews and questionnaires are far enough apart that 
mothers with delayed development children were unlikely systematically to under- or overestimate using a cell phone during pregnancy compared to mothers of children with no delayed development. In general, research looking at the agreement between self-reported cell phone use and usage measured by billing or subscription records concludes that individuals tend to overestimate call duration and underestimate the number of calls $(29,30)$.

As participation in each round of interviews and questionnaires was voluntary for mothers, it is possible that data were collected for mothers and children participating in the DNBC at only some time points such as 6 months and age 7 years and not have information available at 18 months for the infant. Thus we observed a consistent proportion of infants for whom data concerning the outcome was missing (19-22\%), but it does not appear that missing data varied differentially for covariates, which might have indicated systematic error due to selection.

Developmental delays are not routinely captured from hospitalization records except for the most severe of conditions (ie, autism, mental retardation, etc.). Thus it is difficult to use an independent data source that captures the outcomes for this research question to validate our data, since these outcomes are more common and less severe - not receiving or requiring specific medical attention. It should also be noted that the DNBC's assessment for developmental delays was only until age 18 months. Associations of prenatal cell phone use and delays up to the age of 5 years were not assessed.

As the DNBC is a large cohort study, any direct clinical case ascertainment is cost prohibitive. Using interviews and questionnaires conducted by mothers is a more efficient method of gathering information. Since interviews were conducted in a timely manner, mothers would be reporting milestone attainment in real time. In fact, parental reports of developmental delays appear to strongly predict the results of detailed clinical inventories, brain imaging, as well as genetic testing completed for the assessment of developmental milestone delays in the clinical setting (31). Thus we are reassured that direct, timely assessments from mothers is a valid approach in collecting data for this outcome.

Reporting of developmental milestones need not pick up subtle delays in brain development or delays that first manifest later in life. It is possible that more sensitive psychological instruments would have detected delays that this study did not capture, but we have no reason to expect such an effect. A study based upon inperson psychological testing would furthermore have shortcomings such as more non-responders and measurement error related to different levels of contact between a given psychologist and child.

Based upon the results of this study, there does not appear to be any evidence to support an association between prenatal cell phone use and motor and cognitive/language developmental milestone delays among children before the age of two.

\section{Acknowledgements}

The Age-7 questionnaire has received financial support from the Lundbeck Foundation (195/04) and the Danish Medical Research Council (SSVF 0646). Financial support for this analysis was provided by the UCLA School of Public Health, Research Innovation Seed Grant (4565963LK19914) and the study was partially supported by an NIH/NIEHS grant (R21ES016831). This study has received human ethics review approvals from the Danish Data Protection Agency (Datatilsynet) and UCLA Office for the Protection of Research Subjects.

\section{References}

1. International Telecommunication Union. Measuring the Information Society: The ICT Development Index [Internet]. Geneva: International Telecommunication Union, 2009. http:// www.itu.int/ITU-D/ict/publications/idi/2009/index.html [last accessed September 2009].

2. International Telecommunication Union. ITU sees 5 billion mobile subscriptions globally in 2010: Strong global mobile cellular growth predicted across all regions and all major markets [Internet]. Geneva: International Telecommunication Union, 2010. http://www.itu.int/newsroom/press_releases/2010/06. html [last accessed March 2010].

3. Schoemaker MJ, Swerdlow AJ, Ahlbom A, Auvinen A, Blaasaas KG, Cardis E, et al. Mobile phone use and risk of acoustic neuroma: results of the Interphone case-control study in five North European countries. The British Journal of Cancer. 2005;93:842-848.doi:10.1038/sj.bjc.6602764.

4. Lönn S, Ahlbom A, Hall P, Feychting M. Mobile phone use and the risk of acoustic neuroma. Epidemiology. 2004;15:653-659. doi:10.1097/01.ede.0000142519.00772.bf.

5. INTERPHONE Study Group. Brain tumour risk in relation to mobile telephone use: results of the INTERPHONE international case-control study. Int J Epidemiol. 2010;39:67594. doi:10.1093/ije/dyq079.

6. International Agency for Research on Cancer. IARC classifies radiofrequency electromagnetic fields as possibly carcinogenic to humans [Internet]. Lyon: World Health Organization, 2011. http://www.iarc.fr/en/media-centre/pr/2011/pdfs/pr208_E. pdf. [last accessed June 2011].

7. Divan HA, Kheifets L, Obel C, Olsen J. Prenatal and postnatal exposure to cell phone use and behavioral problems in children. Epidemiology. 2008;19:523-529. doi:10.1097/ EDE.0b013e318175dd47. 
8. Divan HA, Kheifets L, Obel C, Olsen J. Cell phone use and behavioural problems in young children. J Epidemiol Community Health. 2010 Dec 7. [Epub ahead of print].

9. Kheifets L, Repacholi M, Saunder R, van Deventer E. Sensitivity of children to EMF. Pediatrics. 2005;116:e303-313. doi:10.1542/peds.2004-2541.

10. Dimbylow P J, Nagaoka T, \& Xu X G. A comparison of foetal SAR in three sets of pregnant female models. Physics in Medicine \& Biology. 2009;54:2755-2767. doi:10.1088/00319155/54/9/011.

11. Dimbylow P. SAR in the mother and foetus for RF plane wave irradiation. Physics in Medicine \& Biology. 2007;52:37913802. doi:10.1088/0031-9155/52/13/009.

12. Volkow ND, Tomasi D, Wang GJ, Vaska P, Fowler JS, Telang F, et al. Effects of cell phone radiofrequency signal exposure on brain glucose metabolism. JAMA. 2011;305(8):808-13.

13. World Health Organization. Children's EMF Research Agenda. Radiofrequency fields - Epidemiological studies [Internet]. Geneva: World Health Organization, 2005. http://www.who. int/peh-emf/research/children/en/index $4 . h t m l$ [accessed June 2007].

14. Identification of Research Needs Relating to Potential Biological or Adverse Health Effects of Wireless Communications Devices. Washington, DC: The National Academies Press, 2008.

15. Goswami U, editor. Blackwell Handbook of Childhood Cognitive Development. Malden (MA): Blackwell; 2002.

16. Grantham-McGregor S, Cheung YB, Cueto S, Glewwe P, Richter L, et al. Developmental potential in the first 5 years for children in developing countries. Lancet, The. 2007;369:6070. doi:10.1016/S0140-6736(07)60032-4.

17. Simeonsson RJ, Sharp MC. Developmental delays. In: Hoekelman RA, Friedman SB, Nelson NM, et al, editors. Primary Pediatric Care. St. Louis: Mosby-Year Book, 1992; pp867-870.

18. Simpson GA, Colpe L, Greenspan S. Measuring functional developmental delay in infants and young children: prevalence rates from the NHIS-D. Paediatric and Perinatal Epidemiology. 2003;17:68-80. doi:10.1046/j.1365-3016.2003.00459.x.

19. Ruffin NJ. Understanding Growth and Development Patterns of Infants [document on the Internet]. Virginia Cooperative Extension. Available from: http://www.ext.vt.edu/pubs/ family/350-055/350-055.html [accessed April 2008].
20. Olsen J, Melbye M, Olsen SF, et al. The Danish National Birth Cohort--its background, structure and aim. Scandinavian Journal of Public Health. 2001; 29:300-307. doi:10.1177/140 34948010290040201.

21. Bech BH, Nohr EA, Vaeth M, Henriksen TB, Olsen J. Coffee and fetal death: a cohort study with prospective data. American Journal of Epidemiology. 2005; 162:983-990. doi:10.1093/ aje/kwi317.

22. Danish National Birth Cohort.. Access to DNBC Data. Data Available. [Internet]. Copenhagen: Serum Statum Institut. [accessed March 2011].

23. Pedersen CB, Gøtzsche H, Møller JO, \& Mortensen PB. The Danish Civil Registration System. A cohort of eight million persons. Danish Medical Bulletin. 2006;53:441-449.

24. Knudsen LB, Olsen J. The Danish Medical Birth Registry. Danish Medical Bulletin. 1998;45:320-323.

25. Vrijheid M, Martinez D, Forns J, Guxens M, Julvez J, Ferrer $M$ et al. Prenatal exposure to cell phone use and neurodevelopment at 14 months. Epidemiology. 2010;21:1-4. doi:10.1097/EDE.0b013e3181cb41e0.

26. Dimbylow P. SAR in the mother and foetus for RF plane wave irradiation. Phys Med Biol. 2007;52:3791-3802. doi:10.1088/0031-9155/52/13/009.

27. Dimbylow PJ, Nagaoka T, Xu XG. A comparison of foetal SAR in three sets of pregnant female models. Phys Med Biol. 2009;54:2755-67. doi:10.1088/0031-9155/54/9/011.

28. Wiart J, Hadjem A, Wong MF, et al. Analysis of RF exposure in the head tissues of children and adults. Phys Med Biol. 2008;53:3681-95. doi:10.1088/0031-9155/53/13/019.

29. Vrijheid M, Armstrong B K, Bdard D, Brown J, Deltour I, et al. Recall bias in the assessment of exposure to mobile phones. Journal of Exposure Science and Environmental Epidemiology. 2009;19:369-81. doi:10.1038/jes.2008.27.

30. Vrijheid M, Cardis E, Armstrong BK, Auvinen A, Berg $\mathrm{G}$, and Blaasaas $\mathrm{KG}$, et al. Validation of short-term recall of mobile phone use for the Interphone Study. Occupational and Environmental Medicine. 2006;63:237-243. doi:10.1136/oem.2004.019281.

31. Tervo R C, Asis M. Parents' reports predict abnormal investigations in global developmental delay. Clinical Pediatrics. 2009;48:513-521. doi:10.1177/0009922809332592.

Received for publication: 21 December 2010 